\title{
EXCAVATING 'HELL UPON EARTH' TOWARDS A RESEARCH FRAMEWORK FOR THE ARCHAEOLOGICAL INVESTIGATION OF WORKERS' HOUSING: CASE STUDIES FROM MANCHESTER, UK
}

\author{
MICHAEL NEVELL
}

\section{ACCEPT AUTHOR'S MANUSCRIPT: 1 OCTOBER 2017}

PUBLICATION: INDUSTRIAL ARCHAEOLOGY REVIEW VOLUME 39 FOR 2017

\section{SUMMARY}

This paper uses 16 years of targeted fieldwork on excavating workers' housing in the Manchester region, UK, to assess a variety of research approaches to the investigation of urban industrial housing of the late $18^{\text {th }}, 19^{\text {th }}$ and early $20^{\text {th }}$ centuries. Manchester was one of the 'shock' cities of industrial Britain, and a honey pot for social commentary during the Victorian period. Using data from more than 30 excavation sites it looks at the way in which archaeological evidence can be used to explore issues around house build quality, overcrowding, sanitation and disease, and reconstructing households from their material remains. Manchester's reputation for poor living conditions during the industrialising period was crystalized around the comments of contemporary social commentators from Engels to Gaskell. Yet, the archaeological evidence reviewed in this article demonstrates the value of archaeological approaches in challenging and testing such views through detailed case studies. More importantly, it shows that archaeological material can be used to study directly features of the new industrialised form of urban living, providing a set of research questions applicable across the industrial urban workers' housing of Britain.

KEYWORDS: Workers' Housing, Manchester, Build Quality, Overcrowding, Sanitation, Households

\section{INTRODUCTION: ARCHAEOLOGY AND INDUSTRIAL HOUSING 1990 TO 2017}

The excavation of urban, Industrial Period, workers' housing was pioneered in several places in the late $20^{\text {th }}$ century: in New York in the USA and Sydney in Australia for instance (1) (Yamin 2001; Karskens 2001). In Britain the archaeological investigation of workers' housing only became a significant method of investigation after 1990 when UK planning guidance required developers to fund archaeological work ahead of redevelopment. Even then it took the long economic boom of 1992 to 2008 to turn the excavation of workers' housing from an exceptional occurrence to one that is now a standard part of archaeological urban planning conditions. From a few excavations in the late 1990s in parts of London such as Spitalfields (2) (Harward, Holder \& Jeffries 2015), the 2000s saw major areas of industrial workers' housing targeted archaeologically in industrial cities including Glasgow, Manchester, Sheffield and York. An example of the continued tradition of standing building analysis is Alcock's historical and architectural study of court housing in Atherstone and Coventry in the English Midlands which marries detailed documentary evidence with building recording. This focus on industrial housing in their urban setting has not been exclusive, although rural studies that focused on excavating workers' housing, such as the work at Alderley Sandhills in Cheshire and Warburton in Greater Manchester, are less common (3) (Alcock 2005; Casella \& Croucher 2010; Nevell with Carney, Cracknell, Haworth, Hill \& Jubb 2015). 
There are now many 'grey literature' studies that is unpublished technical archaeological reports, of excavated workers' housing. However, publication either as specific case studies or as synthetic material has been slow. The first occurrence of excavated workers' housing in the journals Industrial Archaeology Review and Post-Medieval Archaeology was the same site; the 1790s tenement houses associated with the upper forge at Ironbridge. Both journals have published articles on surviving workers' housing since Jennifer Tann's study of fireproof workers' housing in a factory colony in Staffordshire (4) (Belford 2003; Belford \& Ross 2004; Palmer \& Orange 2016; Tann 1972). Later studies include a series of articles on housing quality in Lancashire factory colonies by Geoff Timmins, industrial workers' housing in West Yorkshire, and studies of handloom weavers' dwellings in the Cotswolds, and workers' housing in Essex (5) (Palmer \& Neaverson 2003; Crosby, Garwood \& Corder-Birch 2008, Dewhurst 1986 \& 1989; Timmins 1979; 2000; 2013). More recently, individual excavation case studies on back-to-back and cellar dwellings in Manchester and Sheffield have been published in both journals (6) (Nevell 2014; Wooler 2015).

Notable monograph case studies include Dwyer's analysis of workers' housing in the east end of London and a study of the 'rookery' area of $19^{\text {th }}$ century slum housing north of Smithfield Market in London. In the Manchester region there are significant case studies such as Miller and Gregory's work on $19^{\text {th }}$ century industrial workers' housing in central Bury and Miller and Wild's excavations of late $18^{\text {th }}$ and $19^{\text {th }}$ century weavers' cottages and industrial housing in Angel Meadow in central Manchester. In Sheffield Powell's study of the $19^{\text {th }}$ century steel workers' housing at Hoyle Street, Sheffield, can be seen to build on Symonds' earlier research (7) (Anthony 2011; Dwyer 2011; Miller \& Gregory 2010, Miller \& Wild 2015, Powell 2014; Symonds 2002).

Overviews or syntheses of multiple workers' housing excavations from the UK are rarer. Palmer, Nevell and Sissons (8) (2012) provide a useful overview of industrial workers' housing as a building type relating these to some of the key excavations since 2000. Yet so far only three cities in the UK have significant synthetic studies; Glasgow, Manchester and York.

A detailed overview of the excavations along the M74 in Glasgow in the period 2007-8 was published in 2016 (9) (Nevell 2016). This developer-funded work included the excavation of nine sites, spread across a two-kilometre length of the motorway route, containing more than 60 tenement blocks, a factory colony and villa-style housing. Focussed exclusively on the southern bank of the River Clyde, a major area of urban expansion during the late $18^{\text {th }}$ and $19^{\text {th }}$ century, individual studies would not have captured the rapid change of this area. Consequently, a more thematic approach was taken using these excavations to review how urban Glasgow expanded in this period and how domestic life was changed by industrialisation.

The second British city where there has been systematic investigation of industrial period workers' housing since 2000 is York. Although better known as the most important urban settlement in northern England during the Roman and medieval periods, York was partially transformed in the $19^{\text {th }}$ century into a major railway support town, with its own manufacturing suburbs focussed on engineering and food production. It also has a major study into slum housing conditions undertaken by Seebohm Rowntree and published in 1901. The importance of the archaeological work undertaken in 2007 and 2008 in the Hungate area of the city was that it focussed on the main urban area studied by Rowntree. The initial results of these extensive excavations, taking as its theme $19^{\text {th }}$ and early $20^{\text {th }}$ century poverty, were published in a series of studies in 2011 (10) (Connelly 2011; Rimmer 2011; Walker \& Beaudry 2011). 
By piecing together the details of the construction, ownership, occupation, and adaptation of domestic structures in the form of sophisticated interdisciplinary plot histories, the project provided time-depth to the development of this neighbourhood. In the process it challenged some the traditional Rowntree narrative of this 'slum' area of the city in terms of its supposed poor hygiene and lack of social cohesion.

\section{ARCHAEOLOGY AND INDUSTRIAL HOUSING IN MANCHESTER}

Manchester's central role in industrialisation, that is the shift from a rural agrarian society to an urban-based manufacturing one, drew both praise and scorn in $19^{\text {th }}$ century Britain. The descriptions of Manchester by Friedrich Engels, a member of a Prussian textile mercantile family working in the city in the 1840s, of the housing and living conditions within the city have become infamous. Writing in 1842-43 (though his observations were later published in 1845 in his book 'The Condition of the Working Class in England') he highlighted several areas of the city for their overcrowding, disease and poor house quality, including Ancoats, Little Ireland and New Islington. The worst area, though, was Angel Meadow, the living conditions of which he described as 'hell upon earth'. Engels concluded that the "350,000 working people of Manchester and its environs live, almost all of them, in wretched, damp, filthy cottages, that the streets which surround them are usually in the most miserable and filthy condition, laid out without the slightest reference to ventilation, with reference solely to the profit secured by the contractor" (11) (Engels 1845). His comments can be foreshadowed 50 years earlier by John Aikin writing in 1795; "It [Manchester] unfortunately vies with, or exceeds, the metropolis, in the closeness with which the poor are crowded in offensive, dark, damp, and incommodious habitations, a too fertile source of disease!" (12) (Aikin 1795, 192). Writing over 150 years later in 1963 the social historian Asa Briggs could describe Manchester as the 'shock city' of the Victorian period (13) (Briggs A, 1970, Victorian Cities, 56-57). This was due to the city's central role in developing urban-based steam manufacturing, densely packed urban housing and free market economic theory.

From having no textile mills in 1780 Manchester became the largest mill town in the world, with 33 textile spinning mills in 1800, 86 working steam mills in 1831 and 108 working mills in 1850. Other industries such as engineering, iron and glass making also flourished in the mid$19^{\text {th }}$ century with hundreds of factory sites recorded in 1850 . This phenomenal industrial rise was matched by its spectacular population growth in the first half of the $19^{\text {th }}$ century; Manchester nearly doubled its size between 1801 and 1821 from 75,281 to 126,066 people, and then more than doubled its population by 1851 , when there were 303,382 people within the new borough. This new population required huge amounts of housing and between 1773 and 1821 the number of dwellings in the city rose from 3,446 to 17,257 and by 1851 had reached nearly 50,000 (14) (Hartwell 2001, 17; Kidd 2006, 38; Kidd \& Wyke 2016, 29-30; Nevell 2008).

For most of the $20^{\text {th }}$ century archaeology had little to contribute to the debate on Manchester's role in industrialisation and urbanism. However, beginning in the 1980s archaeological studies of vernacular domestic buildings and the surviving textile factories began to provide a line of archaeological investigation that developed new perspectives on the 'Shock City' (Nevell 2008). At the end of the 1990s a conscious decision was made by the city's planning archaeologists to record actively, during the redevelopment of central Manchester after the IRA bomb damage of 1996, this dwindling resource and to further expand our knowledge by targeting for excavation key city centre urban areas (15) (Redhead 2011, 53-54). Since 2001 archaeological work ahead of redevelopment within the city of Manchester, and central Salford, 
has been targeting the excavation of workers' housing from the $18^{\text {th }}$ and $19^{\text {th }}$ centuries. Over 30 sites have been looked at and the remains of several hundred houses excavated, or more rarely, recorded as standing structures. Some of the worst areas of $19^{\text {th }}$ century slum housing in Britain have been studied, including Angel Meadow in Ancoats, and the New Islington area of Salford.

The archaeological study of workers' housing in the city of Manchester can be traced to the work of the Manchester Early Dwellings Research Group in the 1980s. This group grew out of a Workers' Educational Association class on workers' housing led by Jacqueline Roberts. Spurred by the realisation that significant parts of Manchester's pre-1850 housing stock survived in the city, but was threatened even then by extensive redevelopment, a small group set out to record all the remaining pre-1850 workers' housing in central Manchester and to preserve key examples. Between 1982 and 1993 the group recorded 38 blocks of housing ranging from workshop dwellings and terraced housing to back-to-backs and cellar dwellings. Much of this record, which focused on the Northern Quarter of the city, was through photographic recording although several structures were the subject of detailed archaeological building recording and historical research. The project was successful in raising awareness about the city's early housing stock, and this research led directly to fresh protection for many pre-1850 dwellings either through listing or inclusion in Conservation Areas. Further recording work of early dwellings was undertaken by English Heritage in the 1990s and by the Manchester Region Industrial Archaeology Society in the 2000s and subsequently through the archaeological planning process (16) (Guasden 1988; Parkinson-Bailey 2000, 33-40; Redhead 2011, 53-54; Roberts 1983; 1985, 1993; Taylor \& Holder 2008).

However, the fact that more than two thirds of the sites recorded by MEDREG have subsequently been demolished highlights how vulnerable such small-scale dwellings are to redevelopment and the ravages of time. More importantly, the steady loss of such early dwellings brought about the realisation that archaeological excavation offered a way forward in further exploring these sites.

\section{ARCHAEOLOGICAL EXCAVATION IN MANCHESTER 2001 TO 2017}

Though the first archaeological excavation of workers' housing in Manchester was undertaken by Prof Barri Jones of Manchester University on Deansgate in 1972 this pioneering research was not followed by further digs until the early $21^{\text {st }}$ century. Between 2001 and 2017 (17) (Jones \& Grealley 1974; Nevell 2017; Redhead 2011) more than 30 workers' housing sites have been excavated within the historic $19^{\text {th }}$ century mercantile and manufacturing city centre, and a further six on the Salford bank of the River Irwell, opposite Manchester Cathedral. Many of the areas studied archaeologically were the subject of detailed commentary by social reformers such as Friedrich Engels and Elizabeth Gaskell, or surveys by the local health inspection authorities. This has allowed comparison of the written with the archaeological record, which it turns out often proved to be at odds with each other (18) (Nevell $2011 \& 2014$ ).

A number of research questions have been pursued by archaeologists excavating such sites in Britain. Amongst the most common are issues of: build quality; identity, movement and migration; overcrowding; and sanitation and disease. Furthermore, most of these topics overlap with the concerns of $19^{\text {th }}$ century social commentaries on Manchester from local health inspectors and local health boards to social campaigners such as Edwin Chadwick, Charles Dickens, Dr J P Kay and de Tocqueville in the 1830s and 1840s (18) (Kidd \& Wyke 2016; Roberts 1985, 48-50). Whilst archaeologists must always be wary of following other 
disciplines' agendas (19) (Johnson 1999), archaeological investigation of industrial period housing in Manchester is engaging with other forms of historical evidence in order to highlight the unique qualities that an archaeological approach brings to the study of these issues.

\section{BUILD QUALITY}

Manchester was one the places which social commentators highlighted as having the worst quality of housing in British cities, along with Glasgow and London. Dr J Farriar writing in 1805 described the average worker's dwelling in Manchester as consisting of 'two rooms, the first of which is used as a kitchen, and though frequently noxious by its dampness and closeness, is generally preferable to the back room. The latter has only one small window, which though on a level with the outer ground, is near the roof of the cellar' (20) (Miller, Wild $\&$ Gregory 2010, 25). Engels in 1844 noted that in Ancoats 'in such a hole [referring to a oneroomed house] I found two beds, which with a staircase and chimney-place, exactly filled the room. Everywhere, before the doors, heaps of debris, refuse and offal' (21) (Engels 1845). As late as 1904, when The Citizens' Association of Manchester commissioned a detailed map of housing quality in the city, there were still dozens of occupied back-to-back houses, and hundreds of properties without running water or dedicated toilets (by then condemned as slum dwellings) in Ancoats, Hulme and central Salford. The worst quality housing formed a ring nearly completely encircling the commercial core of Manchester (22) (Marr 1904).

The control of building quality through local bye laws only came about with the creation of local health boards and later local councils in the mid- $19^{\text {th }}$ century. These new bodies used private Acts and local bye-laws to address housing problems in individual towns. Thus, in Manchester the Police Commissioners (established in 1792) and then the new Borough Council (established in 1838) were responsible for taking action to improve the draining and paving of streets. After 1792 the Commissioners introduced a series of bye-laws controlling street widening and improvement as well as building regulations that specified the requirement for and condition of party walls, joists, load bearing timbers and chimneys. A Nuisance Committee was setup in 1800 to deal with the dangers posed by projecting cellar steps and unfenced cellar holes, whilst in 1801 a party-wall surveyor was appointed. By 1811 the Commissioners were repairing soughs and drains from police funds and in 1830 a minimum street width of 24 feet (7.32m) was decreed (23) (Roberts 1993, 21). The Police Commissioners came to act as the de facto council for the rapidly expanding industrial town, recognising that bad sanitation and poor building quality were threats to health and public order. The Manchester Police Act of 1844, sponsored by the new borough of Manchester, apart from establishing judicial courts in the industrial town had clauses allowing the new local authority to insist on the provision of privies for new houses and to ban the building of new back-to-back properties Before the 1844 Manchester Police Act, local land owners might stipulate some restrictions in terms of house plot-size and road width but, as was common in urban centres outside London, control of the type and quality of building material, room size and the provision of utilities was rare. In 1853 a new local bye-law allowed the Borough to prevent the building and habitation of cellars, thus rendering illegal a complete class of dwelling. In the following decade the privately sponsored Manchester Waterworks and Improvement Act of 1867 was aimed at removing back-to-back houses from the city. Thus, it required landlords to renovate, recondition or change the use of existing back-to-backs. This was a very significant moment since, until 1867, all of these regulations applied to new-build properties, not the earlier housing stock, with the exception of the banning of cellar dwellings (24) (Kidd \& Wyke 2016, 315; Roberts 1983, 23). 
Archaeology has been very adept at recovering the structural evidence for the build quality of the new urban industrial homes of $19^{\text {th }}$ century Britain. Across Manchester and Salford this is reflected in the depth and quality of housing foundations and in the quality of the materials used. Build quality varied greatly, but often excavated evidence reveals the substantial nature of much of the housing of the late $18^{\text {th }}$ and $19^{\text {th }}$ centuries in the two cities. The excavation of late $18^{\text {th }}$ century workshop dwellings and terraced housing in Ancoats, Angel Meadow and Castlefield testifies to this. Workshop dwellings typically had substantial half-basements (used as workshops) often with separate heating, lighting and stone-flagged floors as at Southern Street in Castlefield and Angel Street in Angel Meadow (25) (Miller \& Wild 2015, 12-14; Nevell 2008, 144). Late $18^{\text {th }}$ century terraced houses with substantial brick foundations have also been excavated in Ancoats along Loom Street and in Salford along Chapel Street (Nevell 2008, 146-150). Later $19^{\text {th }}$ century board housing in Ancoats also had substantial brick foundations (though no cellars) with running water, paved surfaces and individual back yards and outside toilet blocks (26) (Nevell 2014).

Yet many urban excavations in Manchester and Salford have also revealed poorly-built housing, especially amongst the court, back-to-back and blind-back housing of the first half of the $19^{\text {th }}$ century. One set of four blind-back houses in Salford, at the junction of Gravel Lane and Greengate, built around 1820, had brick foundations resting on the clay subsoil, not laid in a foundation trench, with internally the only evidence for a floor surface being a series of clay levels (27) (Nevell 2008, 149-150). Though of two storeys there was no sign of a staircase suggesting that a wooden ladder might have been used. There was of course no sign of running water and no external privies close by. Other blind-backs could be better appointed. The eight examples excavated at Bury's Court off Adelphi Street in Salford, also built in the early 1820s, had paved floors and staircases, for instance, although they had to share four ash or earth closets and none of the properties originally had running water. Though few single-room dwellings have been excavated in Manchester the dwellings in the cellars of the lodging house on Factory Street in Angel Meadow illustrate how cramped these structures could be at $3 \mathrm{~m}$ by $3.5 \mathrm{~m}$ in area (28) (Gregory \& Miller 2015, 45; Miller \& Wild 2015, 41).

At Piccadilly Place off London Road in central Manchester some of the earliest back-to-backs in the city were excavated in 2009. Built around 1800 and extended in the period 1837-50 the earliest dwellings in Syer's court had purpose-built cellar dwellings, with rooms of roughly $12 \mathrm{ft}$ by $15 \mathrm{ft}(4.27 \mathrm{~m} \times 4.57 \mathrm{~m})$. The internal partitions were one full brick-length deep and each had a flagged floor, fireplace, and separate stone stairways from the street above. The additional properties, built 30 years later, had internal partitions just one brick-width deep, and only communal stairway access to the street. None had running water or drains (29) (Miller, Wild \& Gregory 2010, 26-28).

In Ancoats various sets of back-to-backs were excavated along Loom Street in 2007. One set on the northern side of Jepson's Court, built in the years 1807 to 1813, had paved and heated cellars but were dug into clay. The only drainage was a soakway in the court. This meant that they were prone to flooding when it rained. These properties appear never to have been upgraded with running water. The back-to-backs excavated on George Leigh Street, also in Ancoats, built by 1815 were a slight improvement in that they had no cellars, but they also still had no running water (30) (Miller \& Wild 2015, 43; (Nevell 2008, 156-7; Nevell 2014, 61-66.

\section{OVERCROWDING}


Archaeologically, the evidence for overcrowding in the new industrial towns and cities of the late $18^{\text {th }}$ and $19^{\text {th }}$ centuries can be seen in several ways through the archaeology of the worker's house. The first of these is the subdivision of existing properties by the addition of internal partition walls and external access ways (new doorways, corridors and alleys). The second way overcrowding can be tracked archaeologically is through backyard infilling leading to court areas accessed by narrow passageways from the main streets. Finally, the construction of purpose-built back-to-back and cellar dwellings represented an attempt at high density housing by local private builders. Subdivision, backyard infilling and back-to-back and cellar dwellings are recorded in most $19^{\text {th }}$ century industrial urban sites, with excavated examples ranging from Birmingham and London, to Salford and York (31) (Connelly 2011; Dwyer 2011; Gregory \& Miller 2015).

Archaeological evidence for subdivision comes from a number of areas of central Manchester. In 2005 the Channel 4 archaeology television programme Time Team excavated a single vernacular workshop on the southern side of Angel Street. This was built in the 1770s as part of a row of four-storey properties, with cellar and attic workshops. Part of the front room and the whole of a rear room were excavated, giving a floor area of roughly $5.4 \mathrm{~m}$ by $4.3 \mathrm{~m}$. A halfpenny was found encased in mortar from the cellar backfill with the date 1775 inscribed, suggested that these properties were built around this date. The front room had a flagstone floor, which might have been later, but the rear room had an original handmade brick floor and both spaces were originally heated. Bancks' directory of 1800 records a Michael Smith, shoemaker, at No. 39 Angel Street, which is the likely address of the excavated property. A single-thick brick wall was later inserted across the cellar to form a front and back room space, whilst a stairwell from the pavement into the cellar was inserted. This is visible on the 1850 sixty inch Ordnance Survey map of the area. The 1851 census shows that on average three families were living in each of the former workshop dwellings along Angel Street. Other $18^{\text {th }}$ century properties excavated in the Ancoats district of Manchester also show evidence for such subdivision in the early $19^{\text {th }}$ century (32) (Nevell 2008, 143-50).

A surviving range of three workshop dwellings on Nos 1-5 Milk Street (later Kelvin Street) were built by Richard and Mary Manchester in 1772-73 and let by that family until sold by them in 1790s. Directory evidence indicates that the family were textile. The layout of the three Milk Street properties shows they were built as a single working unit by the Manchester family. Internally, the ground and first floors of each property acted as the domestic areas, each floor being heated and perhaps divided by a wooden screen and providing a total living area of $50 \mathrm{~m}^{2}$. Below was a cellar accessed only from the individual property, but each third-floor attic room was connected to each other providing three, linked, workspaces with a taking-in door at the rear of the northern-most attic room. On the ground floor a covered passageway between the southern and middle properties led to the rear enclosed courtyard and the area below the takingin door. Archaeological evidence indicates that in the mid $-19^{\text {th }}$ century the doorways between the loft workshops were blocked and new external stairwells added to provide separate road access to the cellars. This allowed at least one family per floor of the building, so that in the 1841 Census as many as 20 people were living in a single property which once accommodated just one family. Thus, a mid- $18^{\text {th }}$-century property for one family was turned into a tenement for four or more families, with no extra provision of privies in the rear yard area and no running water (33) (Nevell 2003; Nevell 2008, 142; Nevell 2011).

Far more common than subdivision was the backyard or courtyard infilling of urban properties. This is a frequent urban indicator of overcrowding and was noted by $19^{\text {th }}$ century commentators in many industrial cities including Chester, Glasgow, Manchester and London (34) (Matthews 
1999; Harward, Holder \& Jeffries 2015; Nevell 2008). This process often created court areas accessed by narrow alleys. One extreme example comes from the Angel Meadow-Shudehill area of Manchester. This was a zone of mid- to late $18^{\text {th }}$ century housing that saw backyard and court housing development in the first half of the $19^{\text {th }}$ century. The area was vividly described by Engels in 1844: 'Here one is in an almost undisguised working-men's quarter, for even the shops and beer houses hardly take the trouble to exhibit a trifling degree of cleanliness. But all this is nothing in comparison with the courts and lanes which lie behind, to which access can be gained only through covered passages' (35) (Engels 1845). The large-scale 60 Inch Ordnance Survey map of the Angel Meadow area of Manchester records in apparent detail the alleyways and courts that were created by this urban infill process. However, excavation has demonstrated that the actual urban pattern was far more intricate than recorded by the Ordnance Survey surveyors. Unrecorded alleyways and backyard cottages were excavated in 2009 between Blakeley Street and Factory Street in an area that was known as St Michael's Square. A similar pattern of previously unrecorded backyard dwellings was seen when an area between Blakeley Street and Back Blakeley Street was excavated (36) (Miller \& Wild 2015, 17-19).

The New Cross area of Chapel Street, in Salford, provides a further case study of infill housing leading to overcrowding. Engels commented that 'The working men's dwellings between Oldfield Road and Cross Lane, where a mass of courts and alleys are to be found in the worst possible state, vie with the dwellings of the Old Town in filth and overcrowding' (37) (Engels 1845, 100). In 2012 nine houses were excavated fronting Chapel Street and George Street, seven of which were built around 1807 and two of which were added as infill by 1831 . Houses 1 to 5 represented Nos 333 to 341 Chapel Street, which trade directories confirmed as commercial premises with dwellings above. The infilling included the addition of earth closets in the small yard to the rear of No. 15 Park Street, and the two infill dwellings to the rear of No 335 Chapel Street and George Street. Both infill houses were accessed via a short alley from George Street, south of No. 333 Chapel Street. There was also alleyway access to House 2 from the northern side of Park Street.

The construction of purpose-built back-to-back and cellar dwellings represented an attempt to provide high density housing at a time of high housing demand caused by inward migration. In Manchester and Salford such housing was a common feature of the expanding urban landscape between 1810 and 1840, the era of the fastest population expansion in both cities, although examples are known from outside this date range.

One of the best excavated examples of purpose-built court housing was excavated in 2012 between Park Street and Barrow Street, south of the Chapel Street site discussed above. Ten structures were identified and all were built as a single phase between 1821 and 1824. These were part of a block of sixteen back-to-back dwellings which fronted Barrow Street and which also had cellar dwellings accessed from Barrow Street. Houses 6 to 10 represented No. 1 to No. 5 Fletchers Court. Houses 11 to 14 represented No. 6 to No. 12 Park Street. Houses 6 to 10 were the northern half of the back-to-backs and were only accessible from Fletchers Court, an area less than $3 \mathrm{~m}$ wide and roughly $30 \mathrm{~m}$ long. Two passages from Park Street to the north (roughly $3 \mathrm{~m}$ wide) and Barrow Street to south (just $1 \mathrm{~m}$ wide) provided access to this court. The average floor size of the back-to-backs was roughly $4 \mathrm{~m}$ by $3.5 \mathrm{~m}$. Back-to-back properties were a common feature of many other urban excavations across central Manchester and although their construction was banned in both Manchester and Salford by 1850 many houses, including the examples at Fletchers Court, were still occupied as late as 1905. 
One model of the way in which overcrowded, slum, housing developed during this period is represented by the upstanding remains of Nos 69-77 Lever Street in the Northern Quarter of Manchester. These began as a speculative development of five-, four-storey, workshopdwellings built progressively over a decade by a plasterer, William Bradley. The first phase spanned the period 1780-88 when a row of five houses was built. These had attic-floor workshops but the basements, ground and first floors appear to have been divided for tenement housing in all but one case. Each house had its own rear yard with an outside privy. The second phase saw two-storeyed extensions, lit separately, built into the rear yard areas by around 1790 and a third phase by 1794 saw one-up-one-down cottages added to the rear of these in turn, facing Bradley Street. By 1831 a five bay, three-storey, warehouse was built across two backyards. Access to the phase two and phase three housing was only from the Bradley Street side of the properties (38) (Taylor and Holder 2008, 24-25). These dwellings encapsulate many of the features of later slum housing; small domestic unit size, poor lighting, restricted access through narrow alleyways and a lack of sanitation (39) (Nevell 2011).

\section{SANITATION AND DISEASE}

Excavation of workers' housing can reveal extensive evidence for the state of sanitation in these properties, and by implication the quality of living conditions and the likelihood of disease. This material complements the evidence for disease from the increasing database of urban post-medieval and industrial-period cemeteries now being excavated through developerfunding. Such work in turn builds upon projects like the excavation of c. 1000 burials from the period 1729 to 1852 at Christ Church, Spitalfields, London, in the late 1980s (40) (Reeve and Adams 1993).

Excavations of industrial workers' housing in Chester, Glasgow, London, Manchester, Sheffield and York have indicated that the most significance features in understanding the role of urban sanitation in the $19^{\text {th }}$ and early $20^{\text {th }}$ century are the presence (or absence) and form of drains, water pipes, and toilets.

Before the first Public Health Act of 1848 the regulation of domestic urban structures focused upon building materials and form rather than sanitation. In London wells and soakways were common during the $18^{\text {th }}$ and early $19^{\text {th }}$ centuries whilst 'proper dry rubbish' (containing potentially useful pottery assemblages similar to the clearance assemblages seen in North America and Australia) was often used to level up ground as the city expanded in the $19^{\text {th }}$ century (41) (Jeffries et al 2009, 332-335). The poorest quality housing in Manchester, Sheffield and York (back-to-backs, blind-backs and court housing) had no running water, localised soak-away drains and shared external earth-closet toilets. This is a frequent theme on excavated workers' housing sites in the centre of Manchester from Ancoats and Angel Meadow, to Castlefield and Hardman Street (42) (Nevell 2008, 146-159; Miller \& Gregory 2010; Miller \& Wild 2015; Rimmer 2011). The latter site had, around 1800, cellar dwellings adjacent to a felt hat works that was using soakway drains which in turn was adjacent to a soda works with its own well. This lack of hygiene controls extended to county and market towns such as Altrincham, Cambridge, Dorchester and Oxford with a similar poor outcome in terms of disease levels and health (43) (Cessford 2009; Nevell 1997; Nevell 2008, 70-71; Trinder 2013, 487-488).

The same archaeological work also reveals extensive evidence for domestic sanitation improvement from the mid- $19^{\text {th }}$ century onwards. This could take three forms. Firstly, the upgrading of a property's utilities with running water being brought into to one room (the 
kitchen or scullery), and the addition in the backyard of a dedicated outside earth closet or flushing toilet. Excavations on Loom Street in Ancoats, in Hulme, and Chapel Street in Salford all show this kind of adaptation during the second half of the $19^{\text {th }}$ century (44) (Connolly 2011; Gregory \& Miller 2015; Matthews 1999; Miller and Wild 2015).

Secondly, as building regulations through local health boards became more common often back-to-back housing would be converted either into a single terrace of houses through the demolition of partition walls or put to non-domestic use. This process can be seen at George Leigh Street in Ancoats. Here the central row of houses was demolished in the 1890s and replaced with a wide alley, beneath which was a drain, whilst the remaining two rows of backto-backs were converted into through houses with individual yards and rear privies. In other parts of Ancoats and Angel Meadow such housing was converted into workshops or warehousing (45) (Miller \& Wild 2015, 43; Nevell 2008, 159-165).

Thirdly, there was the demolition of slum housing, sometimes to be replaced with bye-law terraced housing or with purpose-built council housing as with the 1890s Victoria Tenements and terraces on Anita Street in Ancoats Complete clearance was also a common approach. This happened in Manchester with the building of new railway terminuses at Central Station, Exchange Station and the Great Northern Warehouse. More common was the clearance of working class housing ahead of the construction of urban railway lines from the mid-1830s through the industrialised towns. This has been recorded along the path of the Eastern Counties Railway in Shoreditch, London, (46) (Nevell 2014; Dwyer 2011, 15-19) and along the Oxford Road line lining the Castlefield and Piccadilly stations in Manchester and beneath Exchange Station in Salford.

One striking feature of the archaeological case studies of industrial urban housing from around Britain is that older housing, those properties built before the introduction of local bye-laws, took a long time to be upgraded, or in many cases were not improved at all before eventual demolition. A study of housing in the northern half of Ancoats provides a case-study for the way in which archaeology can show how the introduction of bye-laws and regulations could take decades to affect existing housing (47) (Matthews 1999; Walker \& Beaudry 2011; Nevell 2014).

In 1889 Dr John Thresh presented a paper to the Manchester and Salford Sanitary Association, in which he examined the reasons for the continued high mortality in No. 1 District in Ancoats. This was a 36 acre area between Great Ancoats Street, Oldham Road, Union Street and German Street. Thresh reported that the majority of houses in this district (over 800) had been built before 1830, some even before 1780; about 60 had been built between 1830 and 1850, but none after that last date. Most were two-storey, but there were also several three-storey houses, with a workshop in the garret. Back-to-backs accounted for about a third of the dwellings in the district. Many houses had cellars described as being used as workshops or for storage (48) (Roberts 1993, 19). In 1904 T R Marr reported to the Citizens Association for the Improvement of the Unwholesome Dwellings and Surroundings of the People in Manchester the results of his inspection of nearly 600 dwellings in 12.7 acres of No. 1 District. Almost half the dwellings were four-roomed (ie two-up two-down), whilst a third were still two-roomed, although these were gradually disappearing under pressure from Manchester's Sanitary Committee. There were even three sets of back-to-backs still occupied in 1904 (49) (Marr 1904; Roberts 1993, 20; Nevell 2014, 55).

\section{HOUSEHOLDS, CLEARANCE GROUPS AND MOBILITY}


A more intimate approach to the investigation of the everyday lives of the inhabitants of the new industrial cities is through their rubbish, chiefly but not exclusively in the form of ceramic evidence. One particular methodology, that of studying households through clearance groups, only started to be used significantly in British Post-Medieval and Industrial Archaeology after the turn of the millennium. These studies aim to reconstruct individual household histories by combining tightly defined groups of objects, often from rubbish dumps, pits or back-filled latrines and wells, with the documented occupants of the associated property. Developed in Australia and North America their use is still rare in the UK and some of the best published British examples are, ironically, from small rural communities. There are, nevertheless, several published urban studies from sites in London at Limehouse, Shoreditch, the Spitalfield suburbs and Sydenham. Clearance groups have also been analysed and published from Hoyle Street in Sheffield and the Grand Arcade in central Cambridge (50) (Brennan 2015; Cassella 2009; Cessford 2009; Dwyer 2011; Harward, Holder \& Jeffries 2015; Jeffries et al 2009; Powel 2014).

In Manchester two case studies from Ancoats highlight the advantages and problems in dealing with such urban clearance groups from workers' housing; firstly, the excavation of back-tocourt housing off Jersey Street; and secondly the excavation of 46 houses along Loom Street.

At Jersey Street eight dwellings from a set of ten back-to-court built forming Hall's Court were excavated in 2011. These dwellings were built in a single phase between 1794 and 1800, making them amongst the earliest known such building types in Manchester. The buildings were finally demolished in 1970, further enhancing their importance within Ancoats, as this court housing spans almost the full history of the industrial suburb (51) (Cattell \& Nevell 2011; Nevell 2014, 54-56). The houses are shown in detail on Banck's map of Manchester from 1830. A passageway ran from the eastern side of Jersey Street giving access to the southern row of five back-to-backs. The other side of the passageway was occupied by a school. Hall's Court comprised a block of ten, two-storey, back-to-back properties forming Nos 1 to 7 Hall's Court to the south, Nos. 4 and 6 Jersey Street to the west, and Nos. 2 to 8 Pickford Street to the north). Frederick Engels in his commentary on Ancoats noted that the construction of the workers' houses in the area around Jersey Street was '...on closer examination...evident that the walls of these cottages are as thin as it is possible to make them. The outer walls, those of the cellar, which bear the weight of the ground-floor and roof, are one whole brick thick at most...' (52) (Engels 1845). The properties forming Hall's Court were not cellared, nor were outer walls of the house foundations just a single brick thick. These properties were, then, somewhat superior to those elsewhere on Jersey Street.

After minor alterations in the mid- $19^{\text {th }}$ century, during the 1880 s (identified in the excavations as Phase 3) the buildings at Hall's Court were substantially redeveloped. Goad's Insurance Map of Manchester from 1888 shows that Nos 4 and 6 Jersey Street were extended by knocking through into Nos. 1 and 3 Hall's Court and into No. 2 Pickford Street to create two larger commercial premises which functioned as a hairdressers and general provisions store. Number 5 Hall's Court appeared to have been demolished and replaced by a single storey out building and yard. No. 7 Hall's Court also appears to have been demolished and in its place was a singlestorey, rear, extension to No. 8 Pickford Street. No. 4 Pickford Street was demolished and replaced by a single-storey structure with a front yard possibly serving as an out building for the expanded No. 6 Jersey Street, whilst Nos. 6 and 8 Pickford Street were knocked through to create one larger dwelling. 
Documentary and cartographic sources from the $19^{\text {th }}$ century confirmed Nos. 4 and 6 Jersey Street functioned as commercial premises but had living accommodation on the upper floors. In contrast Nos. 1 to 7 Hall's Court and Nos. 2 to 10 Pickford Street were all private dwellings and census returns and trade directories from the period 1797 to 1881 have established that these properties were occupied by local mill workers (cotton piercers and weavers, almost all in Hall's Court in the period 1851-81) and artisans and trades people (barbers, boatman, chair maker, chair maker, coffee mill maker, dress maker, glaziers, fishmonger, greengrocer, hairdresser, joiner's assistant, lawyer, plaster's labourer, plumbers, provisions dealer, shoemaker, sugar boiler, warehouse worker, and a washer woman). One of the reasons for so many trades was the regular turnover of tenants in Hall's Court and along Pickford Street. Nos 4 and 6 Jersey Street saw longer term tenants, such as James Hardman, hairdresser (1879 to 1920), at No 4. The Census Returns from 1891 and 1901 indicated that Hall's Court had ceased to be used as dwellings and were uninhabited. $20^{\text {th }}$ century Census Returns, rate books and trade directories from the period 1901 to 1961 indicate that Nos 4 and 6 Jersey Street, whilst in use as commercial dwellings, continued to have dwellings in the upper storeys (Phase 4). (53) (Census returns)

The excavations produced a closely stratified group of pottery found in drainage and levelling layers associated with three of the main phases of the buildings. Most of the artefacts were derived from primary and secondary contexts, dating to the $19^{\text {th }}$ century and early $20^{\text {th }}$ century. A small proportion (some black-glazed finewares and some of the cream wares) were dateable to the late $18^{\text {th }}$ /early $19^{\text {th }}$ century when the houses were built. The single largest category of objects was pottery, 81 sherds, mainly from three contexts: two dumping levels and a make-up levelling layer all associated with Phases 2 and 3 of the complex (broadly mid- to late $19^{\text {th }}$ century). This ceramic material formed 17 black-gazed earthen ware vessels, nine cream ware vessels, five brown stoneware vessels, one dark-glazed fineware vessel and one unglazed earthen ware vessel. These were mostly bowls and jars, although there were at least one cream ware plate and one cream ware jug. Of particular note was a pair of pince nez, excavated from a Phase 2 deposit (early to mid-1 $9^{\text {th }}$ century) in No 6 Pickford Street, occupied by the Chapman and Eagle families in the mid-19 $9^{\text {th }}$ century. No. 4 Jersey Street, occupied by the Hardman family from the 1870 s into the early $20^{\text {th }}$ century, produced a clearance group (from the Phase 2 levelling context 27) that might be associated with the Hardman's. This included utilitarian earthenwares used in the kitchen or dairy, stoneware vessels used in the pantry or cellar for cold storage, and fine porcelains and whitewares used at the table. The ceramic assemblage from Jersey Street provides an invaluable insight into the $19^{\text {th }}$ century domestic repertoire from working class dwellings at the heart of the industrial core of $19^{\text {th }}$ century Manchester. Its importance lies in the social history it records, through the material possessions of the residents.

The second case study comes from the excavation of a disparate group of workers' housing along Loom Street, to the north-east of Hall's Court. Seven area excavations in a block of land either side of Loom Street, bounded by George Leigh, Bengal, Sherratt and Blossom Streets (Areas A to G) exposed the complete or partial floor plans of 46 dwellings (54) (Gregory 2007). This represents one of the largest archaeological investigations of late $18^{\text {th }}-, 19^{\text {th }}$ - and early $20^{\text {th }}$-century workers' housing within the city. This work also demonstrated the problems of dealing with fragmentary artefact evidence from an area with both a highly mobile population and extensive later rebuilding.

The excavations at Loom Street produced 1024 finds, representing 768 individual items. Of these the ceramic assemblage amounted to 779 individual stratified fragments of pottery, representing a minimum estimated number of 527 pottery vessels, weighing $23.664 \mathrm{~kg}$. The 
ceramic material falls into two broad-groups according to period; post-medieval (pre-1800) pottery and industrially produced ceramics of the $19^{\text {th }}$ and early $20^{\text {th }}$ centuries. The ceramic assemblage can be sub-divided further into fine tablewares and utilitarian coarsewares. Only a small percentage of the assemblage could be directly associated with the structural remains of late $18^{\text {th }}$ and $19^{\text {th }}$ century worker's housing. Most of the artefacts were derived from secondary and tertiary contexts associated with later demolition and infilling episodes and dated to the later $19^{\text {th }}$ and early $20^{\text {th }}$ centuries. How then to interpret such a fragmentary assemblage?

One important aspect of this material is what it tells us about the general living standards (hygiene and heath), cooking methods, and ornamentation prevalent in these properties (55) (Casella \& Croucher 2010, 108-132). A striking feature of both the Jersey Street and Loom Street material is the dominance of robust storage vessels and jars; not surprising in an era before refrigerated methods of keeping perishable food stuffs was commonly available and before the arrival of disposable packing. Cooking was done over a single fireplace (ranges were not common in these properties) and some houses had structural evidence for coppers (large metal bowls heated from below) suggesting that some of the food eaten would have been boiled. Fragments of teapots were found on both sites though no kettles. A number of objects showed the Victorian concern with hygene and health. The presence of soda water bottles and beer bottles might reflect practical hygene concerns, as most properties did not have access to running water or a well. Likewise, the presence of glass and ceramic medicine jars reflected contemporary concerns with health. Display objects within both site assemblages were limited to fine tablewares and a few glass ornaments, although it's likely that such portable items would have been carried away by the occupants when they moved hosues.

A more overtly 'ethnographic' approach to studying $19^{\text {th }}$-century household finds groupings has been used by archaeologists from the Historical Archaeology tradition in the USA. Here, the focus is on reconstructing neighbourhoods by attempting to combine excavated evidence with building studies and the broad swathe of contemporary documentary data in order to provide a better understanding of the overall context of individual households (56) (Mayne \& Lawrence 1999; Mayne \& Murray 2001), would appear to be one way forward. Jeffries and Owens have suggested that such an approach would be helpful in tackling a particular problem in British industrial urban archaeological studies; the identification of migrant and shifting communities in poor urban districts through their material remains (57) (Owens \& Jeffries 2016). Traditionally, the recovery of such identities through their objects has been difficult in this context. This is usually ascribed to the fragmentary nature of much of the material remains excavated, the paucity of available clearance groups, and some of the urban cleansing strategies adopted by the new industrial city authorities the consequences of which are thought to have removed most of the available material culture in many cities (58) (Nevell 2008; Owens \& Jeffries 2016; Symonds 2005). A poor area such as Ancoats had just such a highly mobile population with a history of later house clearances.

Jeffries and Owens suggested (59) (Jeffries et al 2009; Owens \& Jeffries 2016) that by putting the concept of the mobility of people and things at the heart of a study, and drawing on secure contexts such as privy or pit groups, it should be possible to combine historical data and groups of assemblages to suggest new insights into the material lives of highly mobile communities. They identified three types of mobility relevant to an area such as Ancoats: international, local and micro.

There were no distinctive items that might reflect the international nature of the migration into Ancoats (Irish, Italian, eastern European) during the $19^{\text {th }}$ century. This in itself is suggestive of the way in which the mobile populations within Ancoats perhaps did not carry with them 
artefacts linking themselves with their past. The Loom Street assemblage, both fineware and coarseware types of ceramic, show a remarkable restricted range of forms and decorative treatment, with most ceramic products being manufactured in Manchester and Staffordshire, though a few stoneware bottles were manufactured in Bristol and Glasgow. There was a great degree of repetition of styles within the ceramic groups recovered. This could be the result of demolition spreads of material containing fragments from the same vessel (as was seen in Area C House C2 and Area D House D1) or because the domestic ceramic repertoires of the $19^{\text {th }}$ century inhabitants were utilising standard contemporary items which were easily accessible and affordable. The overall emphasis in the assemblage on finewares as opposed to coarsewares suggested that previously utilitarian products, such as brown stoneware and darkglazed coarsewares were being replaced by cheaper whitewares, such as polychrome-banded factory-produced slipwares, used in the pantry, dairy or kitchen for cold storage.

In terms of local migration the existence of jumbled fragments of mis-matched pottery were noted in just a few of the houses along Loom Street. This may reflect the local movement of transient individuals and families where some items are abandoned whilst others are taken to the new home. Notable small groupings came from Dwellings in Areas D and G which produced two fragments of Black Basalt Ware. Jepson's Court (Area C) produced 39 fragments, including 29 sherds that represented fragments of earthenware, stoneware and whiteware bottles, jars, jugs, and saucers. Area D 1, House 1, also produced fragmentary ceramic remains from a drain: representing a cup and saucer.

Finally, the Ancoats material provides evidence for the daily routines of household life, particularly around cleaning and food preparation. This included objects such as a flat iron, medicine jars and a whetstone. Another strand of object was associated with leisure activities, particularly drinking (beer bottles from Houses E3 and E5) and playing (gaming balls and marbles). These objects would have been moved around individual properties hundreds of times before ending their lives in one of the demolition layers.

\section{CONCLUSION}

The study of surviving industrial workers' housing is well developed in Britain, though rooted in architectural approaches or dominated by studies of particular industrial housing types, such as the workshop dwelling. Furthermore, the survival of exceptional landscapes of workers' housing, as at the factory colonies of Cromford, New Lanark and Saltaire, can give a misleading impression as to the character and quality of Industrial Period urban workers' housing. Detailed studies through archaeological building recording and excavation have only developed since the introduction in 1990 of widespread archaeological planning conditions. This has coincided with largescale urban redevelopment that has forced British archaeologists to confront the evidence for the domestic side of the new industrial towns and cities of the $18^{\text {th }}$ and $19^{\text {th }}$ centuries. Manchester is a type-case for this kind of approach.

The lack of survival of key types of industrial housing in Manchester, the cellar dwelling and the back-to-back house, has meant that until recently any study of the city's $19^{\text {th }}$ century house has begun with the contemporary accounts of this 'hell upon earth' chief amongst them Frederick Engels. Occasionally it has been possible to add as colour a few surviving examples, although by their very nature the existence of such industrial workers' housing in the early $21^{\text {st }}$ century is exceptional and the examples either atypical or heavily altered, often both. Certain types of industrial housing in Manchester have gone or are now very rare survivals, such as back-to-backs and cellar dwellings. This is due to concerted campaigns of clearance and 
conversion since the mid- $19^{\text {th }}$ century. Thus, excavation is already the major means by which this industrial urban housing type is recovered and understood within the broader context of British industrialisation. Within Manchester archaeological excavation now provides another source of evidence to add to the scant survival and the Georgian and Victorian commentaries.

Comparing the archaeological recorded with the written, especially the work of the contemporary social campaigners, highlights the selective nature of the evidence Engels and others used in their arguments. This is especially noticeable in any discussion of build quality. The archaeological evidence in key areas such as Ancoats, Angel Meadow and Chapel Street demonstrates that not all early $19^{\text {th }}$ century industrial urban housing was poorly built. Yet it also it demonstrates the norm of wells, the lack of running water and ubiquity poor drainage in this period. Archaeological evidence also provides many case studies of the way in which good quality housing could be divided and converted into tenements as population pressure increased in the second quarter of the $19^{\text {th }}$ century. Engels in particular talks about overcrowding extensively and the archaeology has so far been unanimous in recording evidence for subdivision and backyard infilling on housing plots before 1850 across Manchester. Local health board officials often worried about the threat of disease outbreaks in the 1830s, 1840s and 1850s and the archaeological data records how slowly sanitation improvements were, amongst the existing housing stock in the second half of the $19^{\text {th }}$ century. Yet the archaeological record also preserves evidence for the house clearance and improvement campaigns in new builds after 1850. Even the shifting, mobile nature of Manchester's migrant population can be captured, at least in part from the archaeological record through clearance assemblages.

The data from more than 30 excavation sites across the city shows how archaeological evidence can be used to explore issues around house build quality, overcrowding, sanitation and disease. It also shows how the techniques of reconstructing households from their material remains used by historical archaeologists in north America and Australia, and the methodology for studying mobile urban populations developed in London, can be applied to the Manchester evidence. Such archaeological data has its own importance and should be seen as a unique data set with its own properties and values that go alongside the historical record but is not subordinate to it. Even the most fragmentary urban housing archaeology can reveal useful data on issues from building quality and identity to poverty, overcrowding and poor sanitation, through a study of clearance artefact groups and those structural elements which regularly saw the most rebuilding activity: entrances, passageways and the fireplace. The Manchester evidence has thus been used in this article to highlight a number of lines of investigation. Those broad topics could form the core of a research framework for investigating British industrial urban workers' housing.

\section{ACKNOWLEDGEMENTS}




\section{Bibliography}

Aikin J, 1795, A Description of the Country Thirty to Forty Miles around Manchester. London.

Alcock N W, 2005, 'Housing the urban Poor in 1800: Courts in Atherstone and Coventry, Warwickshire', Vernacular Architecture 36, 49-60.

Anthony S, 2011, Medieval Settlement to $18^{\text {th }} / 19^{\text {th }}$-century rookery. Excavation at Central Saint Giles, London Borough of Camden, 2006-8. London: Museum of London Archaeology.

Barnwell P S, Palmer M \& Airs M, (eds), 2005, The vernacular workshop: from craft to industry, 1400-1900. Council for British Archaeology Research Report Series 140, York.

Belford P, 2003, 'Forging Ahead on Coalbrookdale: Historical Archaeology at the Upper Forge', Industrial Archaeology Review 25.1, 59-62.

Belford P \& Ross R A, 2004, 'Industry and domesticity: exploring historical archaeology on the Ironbridge Gorge', Post-Medieval Archaeology 38, 215-225.

Brennan N, 2015, 'Working on the Railway: the Risehill Tunnel Navvy Camp, Cumbria', Industrial Archaeology Review 37.2, 99-110.

Briggs A, 1970, Victorian Cities. London: Second Edition.

Brunskill R W, 1982, Houses. London, Collins.

Casella E C, 2009, 'You knew where you were: An Archaeology of Working Households in Turn-of-century Cheshire', in Horning A \& Palmer M, (eds), Crossing Paths or Sharing Tracks? Future directions in the archaeological study of post-1550 Britain and Ireland. Woodbridge: Boydell \& Brewer Ltd, 365-380.

Casella E C \& Croucher S, 2010, The Alderley Sandhills Project: An Archaeology of Community Life in (Post-) Industrial England. Manchester: Manchester University Press.

Cattell S \& Nevell M, 2011, The Workers' Housing on vacant land on the corner of Pickford Street and Jersey Street: an archaeological excavation. Centre for Applied Archaeology: Unpublished client report.

Cessford C, 2009, 'Post-1550 Urban Archaeology in a Developer-funded Context: An Example from Grand Arcade, Cambridge', in Horning A \& Palmer M, (eds), Crossing Paths or Sharing Tracks? Future directions in the archaeological study of post-1550 Britain and Ireland. Woodbridge: Boydell \& Brewer Ltd, 301-321.

Connelly P, 2011, 'Flush with the Past: An Insight into Late Nineteenth-Century Hungate and it's Role in Providing a Better Understanding of Urban Development', International Journal of Historical Archaeology 15.4, 607-616.

Crook P, 2011,'Rethinking Assemblage Analysis: new Approaches to the Archaeology of Working-Class Neighbourhoods', International Journal of Historical Archaeology 15.4, 582593. 
Crosby T, Garwood A \& Corder-Birch A, 2008, 'Workers' Housing in Essex', Industrial Archaeology Review XXX.2, 101-26

Dewhurst L, 1986, Workers Housing in West Yorkshire 1750-1920. RCHME and West Yorkshire Metropolitan County Council.

Dewhurst L, 1989, 'Housing the Workforce: A Case Study of West Yorkshire, 1750-1900', Industrial Archaeology Review XI.2, 117-35.

Dwyer E, 2011, The Impact of the Railways in the East End 1835-2010: Historical Archaeology from the London Overground East London Line. London: Museum of London Archaeology.

Engels F, 1845, The Condition of the Working Class in England, 1845. London: Penguin Classics edition from 2009.

Faucher M L, 1844, Manchester in 1844. Its present condition and future prospects. Translated from the French with copious notes appended by a member of the Manchester Athenaeum. Manchester.

Gausden T, 1988, 'Manchester Early Dwellings Research Group', Manchester Regional History Review 2.1, 37-41.

Gregory R, 2007, Loom Street, Ancoats, Manchester. An Archaeological excavation of late Eighteenth Century and Nineteenth century Workers' Housing. University of Manchester Archaeological Unit: unpublished client report.

Gregory R \& Miller I, 2015, Greater Manchester's Past Revealed 13. Greengate. The Archaeology of Salford's Historic Core. Lancaster: Oxford Archaeology North.

Guillery P, 2006, 'Housing the early-modern Industrial City: London's Workshop Tenements', in Green A \& Leech R (eds), Cities in the World, 1500-2000. Papers given at the Conference for Post-medieval Archaeology, April 2002, Society for Post-Medieval Archaeology, 117-32.

Hartwell C, 2001, Pevsner Architectural Guides: Manchester. London: Penguin Books.

Harward C, Holder N \& Jeffires N, 2015, The Spitalfields A Suburb 1539-c 1880: excavations at Spitalfields Market, London E1, 1991-2007. London: MOLA)

Hughes S, 2008, Copperopolis: Landscapes of the Early Industrial Period in Swansea. Cardiff: Royla Commission on the Ancient and Historical Monuments of Wales.

Jeffries N, Owens A, Hicks D, Featherby R \& Wehner K, 2009, 'Rematerialising Metropolitan Histories? People, Places and Things in Modern London' in Horning A \& Palmer M, (eds), Crossing Paths or Sharing Tracks? Future directions in the archaeological study of post-1550 Britain and Ireland. Woodbridge: Boydell \& Brewer Ltd, 323-350.

Johnson M, 1999, Archaeological Theory: An Introduction. Oxford: Blackwell. 
Jones G D B J \& Grealey S, 1974, Roman Manchester. Altrincham.

Karskens G, 2001, 'Small things, big pictures: new perspectives from the archaeology of Sydney's Rocks neighbourhood', in Mayne A \& Murray T, The Archaeology of Urban Landscapes: Explorations in Slumland. Cambridge University Press, 69-85.

Kidd A, 2006, Manchester. Lancaster: Carnegie Publishing. Fourth Edition.

Kidd A \& Wyke T, (eds), 2016, Manchester. Making the Modern City. Liverpool University Press.

Marr T R, 1904, Housing Conditions in Manchester and Salford. University Press.

Matthews K, 1999, 'Familiarity and contempt: the archaeology of the modern' in Tarlow S \& West S, (eds), The Familiar Past? Archaeologies of later Historical Britain. Routledge, London and New York, 155-79.

Mayne A \& Lawrence S, 1999, 'Ethnographies of place: a new urban research agenda', Urban History 26, 325-348.

Mayne A \& Murray T, 2001, 'The archaeology of urban landscapes: explorations in slumland', in Mayne A \& Murray T, (eds), The Archaeology of Urban Landscapes: Explorations in Slumland. Cambridge: Cambridge University Press, 1-7.

Miller I \& Gregory R, 2010, Greater Manchester's Past Revealed 2. The Rock Triangle, Bury: The Archaeology of an Industrial Suburb. Lancaster: Oxford Archaeology North.

Miller I \& Wild C, 2015, Greater Manchester's Past Revealed 14. 'Hell Upon Earth'. The Archaeology of Angel Meadow. Lancaster: Oxford Archaeology North.

Miller V, 2002, English Garden Cities: An introduction. English Heritage, Swindon.

Nevell M, 1997, The Archaeology of Trafford. A Study of the Origins of Community in North West England before 1900. Chester: Trafford Metropolitan Borough Council with UMAU and GMAU.

Nevell M, 2008, Manchester: The Hidden History. Stroud: History Press.

Nevell M, 2011, 'Living in the Industrial City: Housing Quality, Land Ownership and the Archaeological Evidence from Industrial Manchester, 1740-1850', International Journal of Historical Archaeology 15.4, 594-606.

Nevell M, 2014, 'Legislation and Reality: the Archaeological Evidence for Sanitation and Housing Quality in Urban Workers' Housing in the Ancoats Area of Manchester Between 1800 and 1950', Industrial Archaeology Review 36.1, 48-74.

Nevell M, 2016, The Birth of Industrial Glasgow. The Archaeology of the M74. Edinburgh: Society of Antiquaries of Scotland. 
Nevell M, 2017, 'Industrial Workers' Housing in Britain', in Cassella E \& Nevell M with Chamberlin H S, 2017, The Oxford Handbook of Industrial Archaeology. London: Oxford University Press. Forthcoming.

Nevell M with Carney M, Cracknell J, Haworth J, Hill C \& Jubb D, 2015, Warburton. Glimpses of Rural Life: The Archaeology and History of a Cheshire Village. Birstall: University of Salford.

Newman C \& Newman R 2008, 'Housing the workforce in $19^{\text {th }}$ century east Lancashire: past processes, enduring perceptions and contemporary meanings', Post-Medieval Archaeology 42.1, 181-200.

Owens A \& Jeffries N, 2016, 'Poverty and Things on The Move: Domestic Material Culture, Poverty and Mobility in Victorian London', International Journal of Historical Archaeology 20.4, 804-827.

Palmer M, 2005, 'The workshop: type of building or method of work?' in Barnwell, Palmer \& Airs , 2005, 1-16.

Palmer M \& Neaverson P, 2003, 'Handloom weaving in Wiltshire and Gloucestershire in the $19^{\text {th }}$ century: the building evidence', Post-Medieval Archaeology 37.1, 126-58.

Palmer M, Nevell M \& Sissons M, 2012, Industrial Archaeology: A Handbook. York: Council for British Archaeology Practical Handbook 21.

Palmer M \& Orange H, 2016, 'The archaeology of industry: people and places', Post-Medieval Archaeology 50.1, 73-91.

Parkinson-Bailey J J, 2000, Manchester. An Architectural History. Manchester University Press.

Powel A B, 2014, Steelworks, Crucible Furnaces and Workers' Housing. Archaeological Investigations at Hoyle Street, Sheffield. Dorchester: Wessex Archaeology.

Redhead N, 2011, 'Archaeological Investigations of Workers' Housing in Manchester', North West Labour History 35, 53-57.

Rees R, 2001, Poverty and Public Health 1815-1948. Harlow: Heinemann.

Reeve J \& Adams M, 1993, The Spitalfields Project. Volume 1: the Archaeology. Across the Styx. York: Council for British Archaeology Research Report 85.

Roberts J, 1983, Working Class Housing in Nineteenth Century Manchester. John Street, Irk Town, 1826-1936. Neil Richardson Publications.

Roberts J, 1985, 'Provision of Housing for the Working Classes in Manchester between 1780 and 1914- an historical and topographical study', Memoirs and Proceedings of the Manchester Literary and Philosophical Society 124, 48-67. 
Roberts J, 1993, 'A densely populated and unlovely tract: The Residential Development of Ancoats', Manchester Region History Review 7, 15-25.

Rimmer J, 2011, 'People and Their Buildings in the Working-Class Neighbourhood of Hungate, York', International Journal of Historical Archaeology 15.4, 617-628.

Shrimpton D, 1985, 'Buildings for Framework Knitters in Ruddington, Nottinghamshire', Industrial Archaeology Review VIII.1, 70-77;

Symonds J, 2002, ed., The Historical Archaeology of the Sheffield Cutlery and Tableware Industry 1750-1900. British Archaeological Reports British Series.

Symonds J, 2005, 'Dirty Old Town? Industrial Archaeology and the Urban Historic Environment', Industrial Archaeology Review 27.1, 57-66.

Tann J, 1972, 'Early Fireproof Housing in a Staffordshire Factory Village', Post-Medieval Archaeology 6, 191-197.

Taylor S \& Holder J, 2008, Manchester's Northern Quarter. The greatest meer village. Swindon: English Heritage.

Timmins G, 1979, 'Handloom Weavers' Cottages in central Lancashire: Some problems of Recognition', Post-Medieval Archaeology XIII, 251-72.

Timmins G, 2000, 'Housing Quality in Rural Textile Colonies, c. 1800-c.1850: the Ashworth Settlements Revisited', Industrial Archaeology Review XXII.1, 21-38.

Timmins G, 2013, 'Housing Industrial Workers' During the $19^{\text {th }}$ Century: Back-to-Back Housing in textile Lancashire', Industrial Archaeology Review 35.2, 111-127.

Trinder B, 2013, Britain's Industrial Revolution. The making of a manufacturing people 17001870. Lancaster: Carnegie Publishing Ltd.

Walker J \& Beaudry M, 2011, 'Poverty in depth: A new Dialogue', International Journal of Historical Archaeology 15.4, 629-636.

Wooler F, 2015, 'The excavation of $19^{\text {th }}$ century back-to-back housing and courts and the Kenyon Cutlery Works at the site of the Stephenson's Blake Type Foundry, Upper Allen Street, Kenyon Alley and Edward Street, Sheffield', Post-Medieval Archaeology 49, 313-334.

Yamin R, 2001, 'Becoming New York: the Five Points neighbourhood', Historical Archaeology 35, 1-135; 


\section{NOTES AND REFERENCES}

1 Yamin 2001; Karskens 2001).

2 Harward, Holder \& Jeffries 2015

3 Alcock 2005; Casella \& Croucher 2010; Nevell with Carney, Cracknell, Haworth, Hill \& Jubb 2015.

4 Belford 2003; Belford \& Ross 2004; Palmer \& Orange 2016; Tann 1972)

5 Palmer \& Neaverson 2003; Crosby, Garwood \& Corder-Birch 2008, Dewhurst 1986 \& 1989; Timmins 1979; 2000; 2013.

6 Nevell 2014; Wooler 2015.

7 Anthony 2011; Dwyer 2011; Miller \& Gregory 2010, Miller \& Wild 2015, Powell 2014; Symonds 2002).

8 Palmer, Nevell \& Sissons 2012

9 Nevell 2016.

10 Connelly 2011; Rimmer 2011; Walker \& Beaudry 2011.

11 Engels 1845

12 Aikin 1795, 192).

13 Briggs A, 1970, Victorian Cities, 56-57).

14 Hartwell 2001, 17; Kidd 2006, 38; Kidd \& Wyke 2016, 29-30; Nevell 2008)

15 Redhead 2011, 53-54)

16 Guasden 1988; Parkinson-Bailey 2000, 33-40; Redhead 2011, 53-54; Roberts 1983; 1985 , 1993; Taylor \& Holder 2008).

17 Jones \& Grealley 1974; Nevell 2017; Redhead 2011)

18 Kidd \& Wyke 2016; Roberts 1985, 48-50

19 Johnson 1999)

20 Miller, Wild \& Gregory 2010, 25)

21 Engels 1845).

22 Marr 1904).

23 Roberts 1993, 21

24 Kidd \& Wyke 2016, 315; Roberts 1983, 23).

25 Miller \& Wild 2015, 12-14; Nevell 2008, 144).

26 Nevell 2014).

27 Nevell 2008, 149-150).

28 Gregory \& Miller 2015, 45; Miller \& Wild 2015, 41).

29 Miller, Wild \& Gregory 2010, 26-28).

30 Miller \& Wild 2015, 43; (Nevell 2008, 156-7; Nevell 2014, 61-66.

31 Connelly 2011; Dwyer 2011; Gregory \& Miller 2015).

32 Nevell 2008, 143-50)

33 Nevell 2003; Nevell 2008, 142; Nevell 2011).

34 Matthews 1999; Harward, Holder \& Jeffries 2015; Nevell 2008).

35 Engels 1845).

36 Miller \& Wild 2015, 17-19).

37 Engels 1845, 100

38 Taylor and Holder 2008, 24-25).

39 Nevell 2011).

40 Reeve and Adams 1993).

41 Jeffries et al 2009, 332-335).

42 Nevell 2008, 146-159; Miller \& Gregory 2010; Miller \& Wild 2015; Rimmer 2011).

43 Cessford 2009; Nevell 1997; Nevell 2008, 70-71; Trinder 2013, 487-488). 
44 Connolly 2011; Gregory \& Miller 2015; Matthews 1999; Miller and Wild 2015)

45 Miller \& Wild 2015, 43; Nevell 2008, 159-165).

46 Nevell 2014; Dwyer 2011, 15-19)

47 Matthews 1999; Walker \& Beaudry 2011; Nevell 2014).

48 Roberts 1993, 19).

49 Marr 1904; Roberts 1993, 20; Nevell 2014, 55)

50 Brennan 2015; Cassella 2009; Cessford 2009; Dwyer 2011; Harward, Holder \& Jeffries 2015; Jeffries et al 2009; Powel 2014).

51 Cattell \& Nevell 2011; Nevell 2014, 54-56).

52 Engels 1845).

53 Census returns)

54 Gregory 2007)

55 Casella \& Croucher 2010, 108-132).

56 Mayne \& Lawrence 1999; Mayne \& Murray 2001

57 Owens \& Jeffries 2016).

58 Nevell 2008; Owens \& Jeffries 2016; Symonds 2005

59 Jeffries et al 2009; Owens \& Jeffries 2016) 